\title{
Association Between Angiotensin Converting Enzyme Gene InsertionlDeletion Polymorphism and Coronary Heart Disease in Gaza Strip
}

\author{
Lamia'a Sobhi. Saqer*, Haneen Ahmad. Khammash, Eman Loai. Shurrab, Mariam Nahed. Aabed, \\ Rana Afif. El-Malakh
}

Medical Sciences Department, University College of Science and Technology, Gaza Strip, Palestine

Email address:

lamiaa1912@yahoo.com (L. S. Saqer)

${ }^{*}$ Corresponding author

To cite this article:

Lamia'a Sobhi. Saqer, Haneen Ahmad. Khammash, Eman Loai. Shurrab, Mariam Nahed. Aabed, Rana Afif. El-Malakh. Association Between Angiotensin Converting Enzyme Gene Insertion\Deletion Polymorphism and Coronary Heart Disease in Gaza Strip. International Journal of Biomedical Materials Research. Vol. 4, No. 3, 2016, pp. 18-26. doi: 10.11648/j.ijbmr.20160403.12

Received: October 8, 2016; Accepted: October 17, 2016; Published: November 10, 2016

\begin{abstract}
The insertion $\backslash$ deletion (ID) polymorphism in intron 16 of the $A C E$ gene is a marker for a functional polymorphism, and it is also reported to influence levels of ACE in healthy subjects. $A C E I D$ polymorphism is associated with an elevated risk of thrombosis and may be causally associated with coronary heart disease (CHD). To investigate the association between $A C E$ gene polymorphism and CHD in the Gaza strip population, we conducted case-control study included 260 samples comprised 160 CHD patients and 100 control subjects. Questionnaire interview was applied. Blood samples were collected in EDTA tube for DNA extraction. Polymerase Chain Reaction (PCR) used to detect $A C E I D$ polymorphism. There was significant association between CHD and age, physical activity, education level, occupation, and family history of CHD. No significant association was observed between CHD and gender and smoking. The genotype frequencies were: $I D(36.9 \%, 42 \%), D D(53.8 \%, 54 \%)$ and $I I$ $(9.4 \%, 4 \%)$ in case and control groups respectively. The $A C E I D$ allele frequencies were: $I(27 \%, 25 \%)$ and $D(72.2 \%, 75 \%)$ in case and control group respectively. The $D$ allele was the most frequent allele in both groups. No association between $A C E I D$ polymorphism and gender. The $D D$ genotype was the most frequent in both study groups. There was no statistically significant association between the $A C E I D$ polymorphism and CHD in Gaza strip. The results showed that there was no significant association between the $A C E I D$ gene polymorphism and CHD in Gaza strip.
\end{abstract}

Keywords: Angiotensin Converting Enzyme Gene, Coronary Heart Disease, Polymerase Chain Reaction, Polymorphism

\section{Introduction}

The Angiotensin Converting Enzyme gene ( $A C E)$ located on chromosome 17q23.3 (figure 1), spans $21 \mathrm{~kb}$, and comprises 26 exons and 25 introns [1]. Exon 26 encodes for the functionally important membrane-anchoring domain of the ACE protein [2].

$A C E$ gene codes for the Angiotensin converting enzyme (ACE) which plays an essential role in two physiological systems, one is the production of angiotensin II which is a vasoconstrictor leading to increase of blood pressure (BP), the other role is the degradation of bradykinin [3].

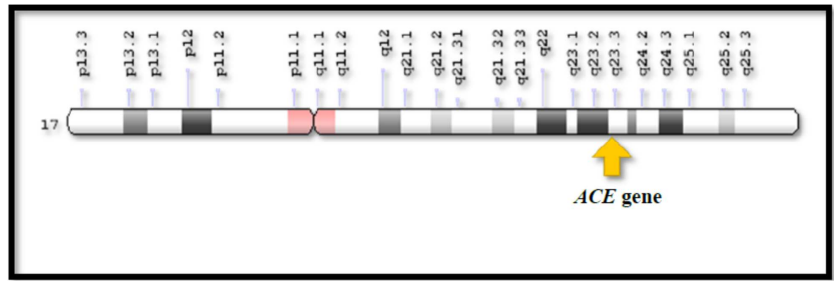

(Adapted from https://ghr.nlm.nih.gov/gene/ACE/location.png)

Figure 1. The location of human ACE gene on the long arm of chromosome 17. 
Most studies focused on an $I D$ polymorphism in intron 16 of the $A C E$ gene as a marker for a functional polymorphism [3]. The polymorphism is due to a $287 \mathrm{bp}$ Alu repetitive sequence in intron 16 of the $A C E$ gene. The fragment is present in the insertion $(I)$ variant and absent in the deletion (D) variant, which results in the three genotypes: Homozygotes $I I$ and $D D$ and heterozygotes $I D$ [4].

$A C E I D$ polymorphism may play a role in the development of many human disorders including renal complications [5] breast cancer [6], prostate cancer [7], coronary heart disease [8], essential hypertension [9], diabetes and nephropathy [10] and end-stage renal disease [11].

Coronary Heart Disease (CHD) is a collective term for diseases that occur when the walls of the coronary arteries become narrowed by a gradual buildup of fatty material called plaques. Deposition of cholesterol on their walls; this reduces the supply of oxygen and nutrients to the heart musculature, which is essential for proper functioning of the heart. This may eventually result in a portion of the heart being suddenly deprived of its blood supply leading to the death of that area of heart tissue, resulting in heart attack [12]. The variability in the prevalence of heart disease risk factors and their association with stroke or ischemic heart diseases in different populations is certainly due to a complex interaction between environmental and genetic factors. The most genetic variation studied contributed to CHD is the $A C E I D$ polymorphism [8]. The presence of $D$ allele would increase the serum concentrations of ACE and this would increase the production of angiotensin $I I$, potent vasoconstrictor that also affects the vascular smooth muscular cells and myocardiocytes increases the synthesis of the extracellular collagen matrix and inhibits physiological fibrinolysis, all of these being mechanisms related to the pathogeny of CHD [13]. It is thought that because of this mechanism the genotype $D D$ of the $A C E$ gene $I / D$ polymorphism is associated with CHD.

In 2014, the Palestinian health information center of the Ministry of Health reported that the CHD was the main cause of Palestinian deaths by $29.5 \%$ of the total reported deaths, according to the report, the number of Palestinian deaths reported 13,297 deaths including 6,601 cases in the Gaza Strip and 6,696 cases in Western Bank. To date, no study has been reported to investigate the association of $A C E$ gene polymorphism and CHD in Palestine.

\section{Methodology}

A retrospective case-control study in which $A C E$ genotyping were performed on 260 individuals who were randomly selected. One hundred and sixty subjects (70 female and 90 male) with CHD and 100 normal subject were included in this study (41 female and 59 male). All subjects were asked to fill a questionnaire. EDTA blood sample were collected from all subjects, 160 patients with CHD recruited from the Nasser and Al Shifa hospitals, and 100 healthy individuals as control. DNA was isolated from fresh EDTA whole blood by using Promega kit for human DNA isolation following the manufacturer's instructions. The quality of the isolated DNA was determined by running $5 \mu \mathrm{l}$ of each sample with $2 \mu$ of DNA loading dye on ethidium bromide stained $1.0 \%$ agarose gels and the DNA was visualized on a short wave U.V. transilluminator.

\subsection{Data Analysis}

The data was enter, stored and analyzed by personal computer using the statistical package for Social Sciences (SPSS) version 20.0. Independent Samples T-test, Chi square test and Odd's Ratio (OR) use to compare between the two group of this study. $\mathrm{P}$ value $<0.05$ will be consider statistically significant.

\subsection{PCR Amplification of ACE Gene}

Polymerase chain reaction (PCR) was used to detect $I D$ polymorphism of $287 \mathrm{bp}$ Alu repetitive sequence near the $3{ }^{\prime}$ end of intron 16 of $A C E$ gene for both groups (case and control).

PCR was performed using the primers described by Chizynski and Cieplucha [14] from genomic extracted DNA using the following oligonucleotide primers:

Forward: 5'CTGGAGACCACTCCCATCCTTTCT'3'

Reverse: 5'GATGTGGCCATCACATTCGTCAGATTT'3

$3 \mu \mathrm{l}(\sim 150 \mathrm{ng})$ of prepared DNA template was added to 7 $\mu \mathrm{l}$ master mix (Bioline, UK), and $0.5 \mu \mathrm{l}$ of each primer $(5$ pmol) in $0.2 \mathrm{ml}$ thin walled microfuge tube. PCR was performed in a thermal cycler (Biometra, Germany). The cycling conditions were: an initial denaturation for $1 \mathrm{~min}$ at $95^{\circ} \mathrm{C}$, followed by 35 cycles of $15 \mathrm{~s}$ at $95^{\circ} \mathrm{C}, 15 \mathrm{~s}$ at $59^{\circ} \mathrm{C}$, $10 \mathrm{~s}$ at $72^{\circ} \mathrm{C}$ and an additional $10 \mathrm{~min}$ at $72^{\circ} \mathrm{C}$ for final extension. Upon completion of PCR, the products were analyzed by electrophoresis on $2 \%$ ethidium bromide stained agarose gel.

\section{Results}

\subsection{Study Population}

The study population consisted of 260 sample (160 case, 100 control). The mean age of subjects was $54.53 \pm 11.8$. The percentage of males was $57.3 \%$ (59\% of control group, $56.25 \%$ of cases) while that of females was $42.7 \%$ (41\% of control group, $43.75 \%$ of cases). $72.3 \%$ of the participants were non- smokers, while about $27.7 \%$ were smokers. $62.3 \%$ of the study population was non-hypertensive subjects, while $37.7 \%$ of them were hypertensive, and about $23.1 \%$ of population had a history of heart thrombosis. On the other hand, $74.2 \%$ of the study population was non diabetic subjects. All hypertensive and diabetic participants were in case group only. Most of the subjects had no family history of CHD.

\subsection{CHD, Education, Occupation and Smoking}

In the overall sample, there was a statistical differences 
in the education level between case and control groups ( $p$ value:0.000). Similarly, there was a significant differences between gender and education level among the subjects (p-value:0.023) with low levels of education among women. (Table 1). Our findings showed that $30.6 \%$ of patients in case group were employees, while $69.4 \%$ of them were not. Moreover, $51 \%$ and $49 \%$ of controls were employee and non-employee respectively ( $p$-value: $0.001)$. There was no statistically significant correlation between smoking and CHD (p-value: 0.630 ). $71.3 \%$ of case group were smokers while $28.7 \%$ of them were not. Moreover $74 \%$ and $26 \%$ of controls were smokers and non-smokers respectively.

Table 1. Relationship between gender, study groups and education.

\begin{tabular}{lllll}
\hline \multirow{2}{*}{ Education } & \multicolumn{3}{l}{ Study group } & \multicolumn{2}{l}{ Gender } \\
\cline { 2 - 5 } & $\begin{array}{l}\text { Case No. } \\
(\%)\end{array}$ & $\begin{array}{l}\text { Control No. } \\
(\%)\end{array}$ & $\begin{array}{l}\text { Male No. } \\
(\%)\end{array}$ & $\begin{array}{l}\text { Female No. } \\
(\%)\end{array}$ \\
\hline Illiterate & $17(10.6 \%)$ & $2(2 \%)$ & $8(5.4)$ & $11(9.9)$ \\
Primary & $61(38.1 \%)$ & $56(56 \%)$ & $59(39.6 \%)$ & $58(52.3)$ \\
Preparatory & $45(28.1 \%)$ & $15(15 \%)$ & $36(24.2 \%)$ & $24(21.6)$ \\
High school & $8(5 \%)$ & $0(0 \%)$ & $3(2 \%)$ & $5(4.5)$ \\
High education & $29(18.2 \%)$ & $27(27 \%)$ & $43(28.8 \%)$ & $13(11.7)$ \\
Total & $160(100 \%)$ & $100(100 \%)$ & $149(100 \%)$ & $111(100 \%)$ \\
P-value & 0.000 & & 0.023 & \\
\hline
\end{tabular}

\subsection{Family History of CHD Among Study Groups}

There was a strong positive relationship between family history and status of participants in study groups ( $\mathrm{p}$-value = 0.000 ). Of cases, $91.7 \%$ had at least one family member with
CHD while only $8.3 \%$ of controls had a family history of CHD. The chance of having CHD was increasing eleven times in people with family history more than those without a family history of CHD (OR:11.00, CI: 4.55-26.61). There is a statistical significance between family history of CHD and gender among case group (p-value:0.009). Female have about 2.4 times of having family history of CHD compared to males (OR: 2.4, CI: $1.2-4.5$ ). (Table 2)

Table 2. Relationship between gender and family history of CHD.

\begin{tabular}{|l|l|l|l|}
\hline $\begin{array}{l}\text { Family history of } \\
\text { CHD }\end{array}$ & $\begin{array}{l}\text { Male No. } \\
(\%)\end{array}$ & $\begin{array}{l}\text { Female No. } \\
(\%)\end{array}$ & $\begin{array}{l}\text { Total No. } \\
(\%)\end{array}$ \\
\hline Yes & $29(32.2 \%)$ & $37(52.9 \%)$ & $94(58.8 \%)$ \\
\hline No & $61(67.8 \%)$ & $33(47.1 \%)$ & $66(41.2 \%)$ \\
\hline Total & $90(100 \%)$ & $70(100 \%)$ & $160(100 \%)$ \\
\hline P- value & 0.009 & & \\
\hline
\end{tabular}

\subsection{History of Heart Thrombosis, Gender, Age, Hypertension (HTN) and Diabetes}

The results of this study showed that there was no statistical significance between the mean of age and previous exposure to heart thrombosis among case group ( $p$-value: 0.190). Also the results revealed that there was a statistically significant difference between history of heart thrombosis and hypertension in case group (p-value:0.002) and the relative of developing heart thrombosis is increasing about three times in hypertensive patients more than nonhypertensive ones (OR: 3.033, CI: 1.48-6.20). While we didn't found any statistical significance between diabetes and history of heart thrombosis (P-value: 0.34) and with smoking (P-value: 0.787) as shown in table 3.

Table 3. Relationship between history of heart thrombosis and some of demographical variables among case group.

\begin{tabular}{|c|c|c|c|c|c|c|}
\hline $\begin{array}{l}\text { History of heart } \\
\text { thrombosis }\end{array}$ & HTN No. (\%) & $\begin{array}{l}\text { Non-HTN No. } \\
(\%)\end{array}$ & Diabetic No. (\%) & $\begin{array}{l}\text { Non Diabetic } \\
\text { No. }(\%) \\
\end{array}$ & Smoker No. (\%) & $\begin{array}{l}\text { Non-smoker No. } \\
(\%)\end{array}$ \\
\hline Yes & $46(46.9 \%)$ & $14(22.6 \%)$ & $28(41.8 \%)$ & $32(34.4 \%)$ & $18(39.1 \%)$ & $42(36.8 \%)$ \\
\hline No & $52(53.1 \%)$ & $48(48.4 \%)$ & $39(58.2 \%)$ & $61(65.6 \%)$ & $28(60.9 \%)$ & $72(63.2 \%)$ \\
\hline Total & $98(100 \%)$ & $62(100 \%)$ & $67(100 \%)$ & $93(100 \%)$ & $46(100 \%)$ & $114(100 \%)$ \\
\hline P-value & 0.002 & & 0.341 & & 0.787 & \\
\hline
\end{tabular}

\subsection{PCR Results}

The amplicon (PCR product) generated from $A C E$ gene should yield a $490 \mathrm{bp}$ or $190 \mathrm{bp}$ long ds. DNA fragment for $I$ and $D$ allele respectively, as giving rise to three genotypes: the homozygotes $I I$ and $D D$, and the heterozygote $I D$ [15]. A negative control (with water instead of the DNA template) was included in each reaction. The size of the amplicon was estimated by comparing it with a DNA molecular size marker (50 bp ladder DNA) run on the same gel. A represented photograph of ACE PCR amplification product is illustrated in figure 2 below. Lane 1 in the figure shows the 50bp DNA marker, $490 \mathrm{bp}$ product in the presence of insertion of Alu repeat ( $I$ allele), and $190 \mathrm{bp}$ fragment in the absence of the $A l u$ repeat ( $D$ allele).

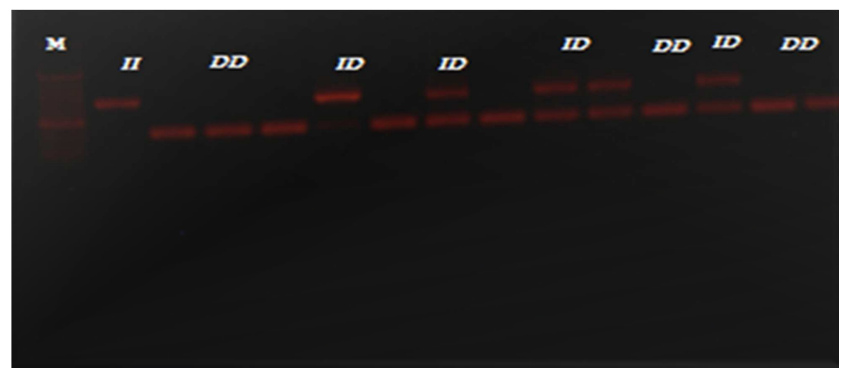

Figure 2. A photograph of ACE gene amplification product:490 bp forII,490 bp and 190 bp for ID, 190 bp for DD genotype. 


\subsection{ACE Alleles and Genotypes Frequencies}

The $A C E$ allele frequencies in the control subjects were $25 \%$ for the $I$ allele and $75 \%$ for the $D$ allele. The frequencies in the CHD group were $27.8 \%$ and $72.2 \%$ for the $I$ and $D$ alleles respectively. The distribution of the subjects according to $A C E$ genotypes were: $D D: 53.85 \%, I D: 38.85 \%$, and $I I$ : $7.30 \%$ (Table 4). The $A C E$ genotype frequencies among study population in the control subjects were $42 \%$ for the $I D$, $54 \%$ for the $D D$, and $4.0 \%$ for the $I I$ genotypes, and in case subject were $36.9 \%, 53.8 \%$ and $9.4 \%$ for $I D, D D$ and $I I$ genotype respectively. As shown in table 4 there was no statistically significant relation between study groups and $A C E$ gene polymorphism (p-value: 0.241 ).

Table 4. Distribution of the ACE alleles and genotypes frequency among the study groups.

\begin{tabular}{llll}
\hline Alleles & Case No. (\%) & Control No. (\%) & Total \\
\hline$I$ & $89(27.8 \%)$ & $50(25 \%)$ & $139(26.73 \%)$ \\
$D$ & $231(72.2 \%)$ & $150(75 \%)$ & $381(73.27 \%)$ \\
Total & $320(100 \%)$ & $200(100 \%)$ & $520(100 \%)$ \\
P-value & 0.48 & & \\
\hline
\end{tabular}

\begin{tabular}{llll}
\hline $\begin{array}{l}A C E \\
\text { genotype }\end{array}$ & $\begin{array}{l}\text { Case group No. } \\
(\%)\end{array}$ & Control No. (\%) & Total \\
\hline$I D$ & $59(36.9 \%)$ & $42(42 \%)$ & $101(38.85 \%)$ \\
$D D$ & $86(53.8 \%)$ & $54(54 \%)$ & $140(53.85 \%)$ \\
$I I$ & $15(9.4 \%)$ & $4(4 \%)$ & $19(7.30 \%)$ \\
\hline
\end{tabular}

\begin{tabular}{llll}
\hline Total & $160(100 \%)$ & $100(100 \%)$ & $260(100 \%)$ \\
P-value & 0.241 & & \\
\hline
\end{tabular}

\subsection{ACE Genotype and Gender}

The results of the study showed that there was no statistically significant difference between the $A C E$ genotype and the gender among study groups (P-value: 0.266 ), and for case group was (P-value: 0.162). The most frequent $A C E$ genotype among male and female in the study population where $D D: 49.7 \%$ and $59.5 \%$ respectively (OR:1.6, CI: $0.91-$ 2.4).

\subsection{Relation Between ACE Genotype, Family History of CHD, Hypertension and Diabetes}

The results showed that there was no risk of developing CHD in the $D D$ genotype group and having family history of CHD when compared with $I D$ and $I I$ genotype group (OR:1.5, CI: 0.87-2.62) (P-value: 0.146). Also results of our study indicated that the most $A C E$ genotype among hypertensive patient in case group was $D D$ genotype (59.2\%), and showed that there was no statistically significant relationship between hypertension and $A C E$ genotype in case group (P-value:0.194), (OR: 1.7, CI: 0.9263.347). There was no statistically significant relation between diabetes and $A C E$ gene polymorphism in case group (pvalue: 0.748$)$, (OR: 0.52, CI: 0.43-1.53). (Table 5)

Table 5. ACE genotype and allele frequencies among the hypertensive and diabetic patients.

\begin{tabular}{|c|c|c|c|c|}
\hline$A C E$ genotype & $\begin{array}{l}\text { With HTN } \\
\text { No. }(\%)\end{array}$ & $\begin{array}{l}\text { Without HTN } \\
\text { No. }(\%) \\
\end{array}$ & $\begin{array}{l}\text { Diabetic } \\
\text { No. }(\%) \\
\end{array}$ & $\begin{array}{l}\text { Non Diabetic } \\
\text { No. }(\%) \\
\end{array}$ \\
\hline$I D$ & $31(31.6 \%)$ & $28(45.2 \%)$ & $27(40.3 \%)$ & $32(34.4 \%)$ \\
\hline$D D$ & $58(59.2 \%)$ & $28(45.2 \%)$ & $34(50.7 \%)$ & $52(55.9 \%)$ \\
\hline II & $9(9.2 \%)$ & $6(9.6 \%)$ & $6(9 \%)$ & $9(9.7 \%)$ \\
\hline Total & $98(100 \%)$ & $62(100 \%)$ & $67(100 \%)$ & $93(100 \%)$ \\
\hline $\mathrm{P}$-value & 0.194 & & 0.748 & \\
\hline Allele Frequency & With HTN (\%) & Without HTN (\%) & Diabetic (\%) & Non Diabetic (\%) \\
\hline$I$ & $25 \%$ & $32.3 \%$ & $29 \%$ & $27 \%$ \\
\hline$D$ & $75 \%$ & $67.7 \%$ & $71 \%$ & $73 \%$ \\
\hline $\mathrm{P}$ - value & 0.16 & & 0.66 & \\
\hline
\end{tabular}

\section{Discussion}

\subsection{CHD and Demographical Variables}

Over the past decade CHD, also known as ischemic heart disease or atherosclerotic heart disease, has been the leading cause of death worldwide, as well as Palestinian territories, with persistently rising incidence [16]. Approximately 80\% of all CHD related deaths occur in low- and middle-income countries [17]. For our knowledge, this study is the first one to investigate the association between $A C E$ gene polymorphism and CHD and to assess the frequencies of the $A C E I D$ genotypes and alleles in Gaza strip.

There is a marked difference in CHD risk between sexes [18]. CHD was approximately 3 times higher in men than women [19]. CHD incidence was $\approx 3$-fold and mortality $\approx 5$ fold among men greater than in women [20]. Sex-specific differences in the prevalence of CHD are known and attributable to biological factors, differences in health behavior, as well as to aspects of medical care [21]. Although studies have shown that hormonal dysfunction in premenopausal women is associated with an increased risk of atherosclerosis and CHD events [22].

One theory on why men suffer from heart disease earlier than women is stress. men still endure more stress from heavy physical activities or actions than women [23].

Genetic variation within the male-specific region of the $Y$ chromosome [24] and dominance of androgens over estrogens [25] have been proposed as the major factors contributing to the male predisposition to CHD [26]. This 
suggests that certain sex hormones may be important risk factors of heart disease. Reduction of estrogen concentrations in menopause leads to changes in female lipid profile by reducing HDL, and elevating apolipoprotein levels, thus increasing the risk for cardiovascular disease [27]. Estrogen may have cardio-protective effects [28] through glucose metabolism and the hemostatic system, and it may also have a direct effect on endothelial cell function [29]. Our findings showed that the percentage of females in CHD group was higher than in control may be due to the advanced age of the women (mean age was 60.03 years).

The findings of the present study showed that $48.8 \%$ of cases were physically low-active. We noted that there was a good agreement with evidence that physical inactivity is one of the major modifiable risk factors for CHD. Physical activity appears to slow the initiation and progression of CHD through salutary effects [30]. Sedentary people have about twice the risk of developing or dying from CHD and $37 \%$ of deaths from CHD can be attributed to physical inactivity [31]. Physical activity prevents the blood vessels from narrowing further (anti-atherosclerotic), prevents blood clotting (anti-thrombotic), helps deliver blood to the heart (anti-ischemic), and helps to maintain a normal heart rhythm (anti-arrhythmic). These changes reduce the load on the heart at rest and during exercise, which helps to lessen some of the symptoms as well as decrease the risk of death from CHD [32].

One major contribution to the increased risk of CHD among smokers is tobacco's effect on increasing overall blood cholesterol levels. This occurs as a result of the chemical acrolein, which affects the way the body processes cholesterol, allowing greater amounts to remain in the blood system [33]. This compound, also decreases the ratio of high HDL,(the "good" cholesterol) to low-density lipoprotein (LDL), (the "bad" Cholesterol) [34]. The risk of heart thrombosis is also raised due to tobacco's effect on fibrinogen levels (a protein which causes blood to clot) and its effects on increased platelet aggregation which makes the blood more sticky [35]. Finally, it has been shown that smoking causes the body's blood vessels to constrict (vasoconstriction) by decreasing nitric oxide which dilates blood vessels and increasing endothelin-1 which causes constriction of blood vessels [36]. The net result is raised blood pressure and a transient reduction in blood supply. Our study showed that the majority of CHD patients were smokers $(71.3 \%)$ but we didn't fount any significant association between smoking and CHD.

Education is a measure of socioeconomic state (SES) that takes into account the person's nonmaterial resources (e.g. knowledge and problem-solving skills). Education can be measured by years of education or the highest educational degree completed, but it is, nevertheless, easy to categorize, obtain and can be measured whether employed or unemployed. In addition, education is usually fixed after early adulthood, and therefore unlikely to be affected by possible poor health of adulthood. [37]. More education are likely to have greater knowledge of health conditions and treatment regimens and have better self-management skills than those with less education [38]. Individuals with low educational levels are less likely to be knowledgeable about the health effects of smoking, particularly the effects of smoking during pregnancy [39].

The educational level of parents can influence child and family health related behaviors. Studies have shown that the education level of mothers is likely to have a greater impact than that of fathers [40]. An association has been found between higher parental education level and increased likelihood of consuming a healthy diet [41]. Adolescents in families with low maternal education may also be more likely to use illegal drugs [42].

Our study, showed that there was a statistical differences in the education level between cases and controls. Similarly, there was a significant differences between gender and education level with low levels of education among women.

There was a strong positive relationship between family history and status of participants in study groups. The chance of having CHD was increasing eleven times in people with family history more than those without any family history of CHD. A study was done in USA reported that the persons with a positive family history of CHD were almost 4 times as likely than those with a negative family history to believe that they were very likely to develop heart disease or stroke in the future. A positive family history of CHD was associated with increase odds of having high blood pressure, compared with persons those having a negative family history [43].

The results of our study showed that the percentage of patients who had previous exposure to heart thrombosis was $37.5 \%$ with mean age of 59.35 years, and $60 \%$ of them was males. We found that $76.7 \%$ of them were hypertensive and $46.7 \%$ were diabetic, while $43.3 \%$ of them were suffering from hypertension and diabetes together. More than half of patient whose had previous heart thrombosis were physically low-active $(65 \%)$. These findings showed agreement with the fact that age, hypertension and diabetes and physical activity are strong risk factors for heart thrombosis. The National Institute of Diabetes and Digestive and Kidney Diseases (NIDDK) had published that having diabetes increases the risk for heart attack at least twice as likely as someone who does not have diabetes. Over time, high blood glucose levels damage nerves and blood vessels, leading to complications such as heart disease and stroke. If someone has high blood pressure his heart must work harder to pump blood. High blood pressure can strain the heart, damage blood vessels, and increase risk of heart attack, stroke, eye problems, and kidney problems (NIDDK, 2013).

\subsection{Genotype Frequencies of ACE Gene in Gaza Strip}

Most studies focused on $I D$ polymorphism in intron 16 of the $A C E$ gene [3]. The polymorphism is due to a $287 \mathrm{bp}$ Alu repetitive sequence in intron 16 of the $A C E$ gene in chromosome 17. The fragment is present in the insertion $(I)$ variant and absent in the deletion $(D)$ variant, which results in the three genotypes: Homozygotes $I I$ and $D D$ and 
heterozygotes $I D$ [4].

The observed genotype frequencies were in HardyWeinberg equilibrium for both groups. According to the results obtained from PCR the $A C E I D$ polymorphism genotype frequencies in Gaza Strip were: II: 7.3\%, ID: 38.8, $D D$ : $53.8 \%$. Table 6 illustrates the distribution of $A C E I D$ polymorphism among some population.

Table 6. Distribution of ACE ID polymorphism for many populations.

\begin{tabular}{|c|c|c|c|c|c|c|}
\hline \multirow{2}{*}{ Country } & \multicolumn{2}{|c|}{ Allele frequency } & \multicolumn{3}{|c|}{$A C E$ genotypes } & \multirow{2}{*}{ Reference } \\
\hline & $I$ & $D$ & $I I \%$ & $I D \%$ & $D D \%$ & \\
\hline Egypt & 0.567 & 0.433 & 39 & 35.5 & 25.5 & Rashed, et al., 2015 [44] \\
\hline Algeria & 0.384 & 0.616 & 11.3 & 54.2 & 34.5 & Semmame, et al., 2015 [45] \\
\hline Kuwait & 0.379 & 0.621 & 17.4 & 41.3 & 41.3 & Al-Serri, et al., 2015 [46] \\
\hline Lebanon & 0.328 & 0.672 & 9.8 & 46 & 44.2 & AlBacha, et al., 2015 [47] \\
\hline Soudi Arabia & 0.398 & 0.602 & 23.45 & 32.8 & 43.75 & Alharbi, et al., 2013 [48] \\
\hline South Indian & 0.36 & 0.64 & 26.7 & 46.7 & 26.6 & Shanmuganathan et al., 2015 [50] \\
\hline Romania & 0.391 & 0.609 & 11.5 & 55.2 & 33.3 & Carmen, et al., 2011 [51] \\
\hline China & 0.362 & 0.638 & 22.6 & 31.3 & 46.1 & Zhou, et al., 2012 [52] \\
\hline Iraq & 0.358 & 0.652 & 19.4 & 29.1 & 51.5 & Al-Jebouri and Al-Alwani, 2015 [53] \\
\hline PalestinelGaza Strip & 0.267 & 0.733 & 7.3 & 38.8 & 53.8 & Present study \\
\hline
\end{tabular}

\subsection{Relationship Between CHD and ACE Gene Polymorphism}

Several studies have been conducted to analyze the relationship between the $I D$ polymorphism of the $A C E$ gene and the development of CHD (Table 7). These studies revealed that the presence of the $A C E$ gene $D D$ variant is associated with an increased risk of developing atherosclerotic and vascular disease [54]. The presence of the $D$ allele homozygotes corresponds to an increased risk of $\mathrm{CHD}$ by an average in 1.3 times [55]. The $D D$ genotype and $D$ allele may serve as the criteria for identifying patient groups which are at high risk for MI and CHD [56]. A studies conducted in Iraq [53], Algeria [45] and Lebanon [47] showed that there was statistically significant between $A C E$ genotype among the study groups which differ from our findings, while there was good agreement between our results and the results that revealed from Turkish one [49].

No significant differences were detected in allele or genotype frequencies between patients and controls ( $\mathrm{p}=$ 0.48 ). Table 7 showed distribution of $A C E I D$ polymorphism for many populations among CHD group and control.

Table 7. Distribution of ACE gene ID polymorphism for cases and controls among different studies.

\begin{tabular}{|c|c|c|c|c|c|c|c|c|}
\hline \multirow{2}{*}{ Country } & \multicolumn{3}{|l|}{ Case } & \multicolumn{3}{|c|}{ Control } & \multirow{2}{*}{ P-value } & \multirow{2}{*}{ Reference } \\
\hline & $I I \%$ & $I D \%$ & $D D \%$ & $I I \%$ & $I D \%$ & $D D \%$ & & \\
\hline Algerian & 14.46 & 46.55 & 38.99 & 8.13 & 61.87 & 30 & 0.02 & Semmame et al., 2015 [45] \\
\hline Turkey & 12.7 & 47.1 & 40.2 & 16.19 & 48.09 & 35.72 & 0.40 & Inanir et al., 2016 [49] \\
\hline Iraq & 13.4 & 28.9 & 56.7 & 35.15 & 29.7 & 35.15 & $<0.05$ & Al-Jebouri and Al-Alwani, 2015 [53] \\
\hline
\end{tabular}

\section{Conclusion}

The results of this study can be summarized as follows:

- In Gaza Strip, the $D D$ genotype was the most common genotype among the control and the CHD groups. ID was the next most common genotypes.

- The frequencies of $A C E$ alleles in the CHD subjects were: $27.8 \%$ for the $I$ and $72.2 \%$ for the $D$. These frequencies are comparable to those found in the control group where: $25 \%$ for the $I$, and $75 \%$ for the $D$.

- No statistically significant differences in $A C E$ genotypes were found between the patients and the control groups and between male and female in terms of the $A C E$ genotypes.

- There is statistical significance in physical activity among study groups, and significant relationship between education level and risk of CHD, and this association was stronger in women participated in this study.
- There was a strong positive relationship between family history and status of participants in study groups. The chance of having CHD was increasing eleven times in people with family history more than those having negative a family history of CHD.

- There was no statistically significant relation between diabetes and hypertension with $A C E$ gene polymorphism in case group, also there was no statistically significant relation between smoking and $A C E$ gene polymorphism among study groups.

Based on the data presented by this study changes in lifestyle and CHD prevention strategies should be followed to reduce risk factor for CHD developing. These strategies include the management of high blood pressure, high blood cholesterol, unhealthy diet and physical inactivity. People should be encouraged to increase their daily physical activities to achieve additional health benefits, by increasing the intensity, duration, or frequency of physical activity. Further studies recommended to establish the role and 
relative contribution of $\mathrm{CHD}$ and candidate genes.

\section{References}

[1] Hubert C., Houot A., Corvol P. and Soubrier F. (1991) "Structure of the angiotensin I-converting enzyme gene. Two alternate promoters correspond to evolutionary steps of a duplicated gene". Journal of Biological Chemistry, 266: 15377-15383.

[2] Koike G., Horiuchi M., Yamada T., Szpirer C., Jacob H. and Dzau V. (1994) "Human type 2 angiotensin II receptor gene: cloned, mapped to the $\mathrm{X}$ chromosome, and its mRNA is expressed in the human lung". Biochemical Biophysiological Res Communty, 203: 1842-1850.

[3] Sayed-Tabatabaei F., Schut A., Va'squez A., Bertoli-Avella A., Hofman A., Witteman J. and Duijn V. (2005) "Angiotensin converting enzyme gene polymorphism and cardiovascular morbidity and mortality: the Rotterdam Study". Journal of Medical Genetics, (42) 26-30.

[4] Frederiksen H., Bathum L., Worm C., Christensen K. and Puggaard L. (2003) "ACE genotype and physical training effects: A randomized study among elderly Danes". Aging Clinical and Exprimental Research, (15) 284-291.

[5] Ciruzzi M., Schargrodsky H., Rozlosnik. J, Pramparo P., Delmonte H., Rudich V., Piskorz D., Negri E., Soifer L. and Vecchia C(1997)." Frequency of family history of acute myocardial infarction in patients with acute myocardial infarction". American Journal of Cardiology, 80: 122-127.

[6] Puay Koh W., Min Yuan J., Lan Sun C., Berg D., Seow A., Hin-Peng Lee. and Mimi C. (2003) "Angiotensin I-Converting Enzyme (ACE) Gene Polymorphism and Breast Cancer Risk among Chinese Women in Singapore." Cancer Research, 63 (3): 573-8.

[7] Yigit B., Bozkurt N., Narter F., Yilmaz H., Yucebas E. And Isbir T. (2007) "Effects of ACE I/D Polymorphism on Prostate Cancer Risk, Tumor Grade and Metastatis". International journal of cancer research and treatment, 27 (2) 933-936.

[8] Cardoso R., Nogueira A., Salis L., Urmenyi T., Silva R., Moura-Neto R., Pereira B., Rondinelli E. and Silva N. (2008) "The association of ACE gene D/I polymorphism with cardiovascular risk factors in a population from Rio de Janeiro". Brazilian Journal of Medical and Biological Research, (41) 512-518.

[9] Ramachandran V., Ismail P., Stanslas J., Shamsudin N., Moin S. and Mohd Jas R. (2008) "Association of insertion/deletion polymorphism of angiotensin-converting enzyme gene with essential hypertension and type 2 diabetes mellitus in Malaysian subjects". Journal of Renin-AngiotensinAldosterone system, 9 (4) 208-214.

[10] Shaikh R., Shahid S., Mansoor Q., Ismail M. and Azhar A. (2014) Genetic variants of ACE (Insertion /Deletion) and AGT (M268T) genes in patients with diabetes and nephropathy." Journal of Renin-Angiotensin-Aldosterone System, 15 (2): 124-130.

[11] Zhou T., Yin S. and Qin Y. (2014) "Association between angiotensin-converting enzyme insertion/deletion gene polymorphism and end-stage renal disease susceptibility". Journal of Renin-Angiotensin-Aldosterone System, 15 (1) 2231.
[12] Akhund S. and Avan B. (2011) "Development and pretesting of an information, education and communication (IEC) focused antenatal care handbook in Pakistan". Biomedical Resarch Notes, 4 (91) 500-1750.

[13] Ruiz-Ortega M, Ruperez M, Esteban V, Egido J. (2003) "Molecular mechanisms of angiotensin II-induced vascular injury". Current Hypertension Reports, 5: 73-79.

[14] Chizynski K., Cieplucha E. (2007). The frequency of appearance of the ID ACE genetic polymorphism in patients with previous myocardial infarction in Polish population. Clinical and Experimental Medical Letters; 48 (3): 173-179.

[15] Dikmen M., Gunes H., Degirmenci I., Ozdemir G. and Basaran A. (2006). Are the Angiotensin-Converting Enzyme gene and activity risk factors for Stroke? Arquivos Neuropsiquiatr, 64 (2) 211-216.

[16] Erhardt L. (2009). Cigarette Smoking: An undertreated risk factor for cardiovascular disease. Atherosclerosis, 205: 23-32.

[17] Gersh J., Karen S., Bongani M. and Salim Y. (2010). The epidemic of cardiovascular disease in the developing world global implications. European Heart Journal Advance Access, 31 (6): 642-650.

[18] Rich-Edwards JW., Manson JAE., Hennekens CH. and Buring JE. (1995) "The primary prevention of coronary heart disease in women." The New England Journal of Medicine, 332: $1758-1766$.

[19] Jousilahti P., Vartiainen E., Tuomilehto J. and Puska P.(1999) "Sex, age, cardiovascular risk factors, and coronary heart disease: a prospective follow-up study of 14786 middle-aged men and women in Finland." Circulation, 99 (9): 1165-72.

[20] Izadnegahdar M., Singer J., Lee M., Gao M., Thompson C. and Kopec J. (2014) "Do younger women fare worse? Sex differences in acute myocardial infarction hospitalization and early mortality rates over ten years". Journal of Womens Health, 23 (1): 10-17.

[21] Pilote L, Dasgupta K., Guru V., Humphries K., McGrath J., Norris C., Rabi D., Tremblay J., Alamian A., Barnett T., Cox J., Ghali W., Grace S., Hamet P., Ho T., Kirkland S., Lambert M., Libersan D., O'Loughlin J., Paradis G., Petrovich M. and Tagalakis V. (2007). "A comprehensive view of sex-specific issues related to cardiovascular disease." Canadian Medical Association Journal 176 (6): S1-S44.

[22] Setji T, Brown A. (2007) "Polycystic Ovary Syndrome: diagnosis and treatment." American Journal Medicine.; 120 (10): 128-32.

[23] Sozzi F., Danzi G., Foco L., Ferlini M., Tubaro M. and Galli M. (2007) "Myocardial infarction in the young: a sex-based comparison" Coronary Artery Disease, 18 (6): 429-431.

[24] Charchar FJ., Tomaszewski M., Lacka B., Zakrzewski J., Zukowska-Szczechowska E., Grzeszczak W. and Dominiczak AF. (2004) "Association of the human Y chromosome with cholesterol levels in the general population." Arteriosclerosis, Thrombosis, and Vascular Biology, 24: 308-312.

[25] Wu FC. and von Eckardstein A. (2003) "Androgens and coronary artery disease.” Endocrine Reviews; 24: 183-217.

[26] Muller M., van A., Bots M., Grobbee D., Lamberts S. and van Y. (2004) "Endogenous sex hormones and progression of carotid atherosclerosis in elderly men." Circulation, 109: 2074-2079. 
[27] Mesalic L., Tupkovic E., Kendic S. and Balic D. (2008) "Correlation between hormonal and lipid status in women in menopause." Bosnian journal of basic medical sciences, 8 (2): 188-192.

[28] Bonithon-Kopp C., Scarabin P., Darne B., Malmejak A. and Guize L.(1990) "Menopause-related changes in lipoproteins and some other cardiovascular risk factors" International Journal of Epidemiology, 19: 42-48.

[29] Shahar E., Folsom A., Salomaa V., Stinson V., McGovern P. Shimakawa T., Chambless L. and Wu K. (1996). For the atherosclerosis risk in communities (ARIC) study investigators. relation of hormone replacement therapy to measures of plasma fibrinolytic activity. Circulation, 93: 1970-1975.

[30] Mujica V., Urzua A., Leiva E., Diaz N., Moore-Carrasco R. and Vasquez M. (2010). Intervention with education and exercise reverses the metabolic syndrome in adults. journal american society hypertension, 4: 148-153.

[31] Britton A. and McPherson K. (2002) Monitoring the Progress of the 2010 Target for Coronary Heart Disease Mortality: Estimated consequences on CHD Incidence and Mortality from Changing Prevalence of Risk Factors. National Heart Forum: 1-60.

[32] Taylor R., Brown A., Ebrahim S., Jolliffe J., Noorani H. and Rees K. (2004) Exercise-based rehabilitation for patients with coronary heart disease: systematic review and meta-analysis of randomized controlled trials. American Journal of Medicine, 116: 682-692.

[33] Tamamizu-Kato S., Yiu Wong J., Jairam V., Uchida K., Raussens V., Kato H., Ruysschaert JM, and Narayanaswami V. (2007) Modification by Acrolein, a Component of Tobacco Smoke and Age-related Oxidative Stress, Mediates Functional Impairment of Human Apolipoprotein E. Biochemistry. 17; 46 (28): 8392-8400.

[34] Gossett L., Johnson H., Piper M., Fiore M., Baker T. and Stein J. (2009) "Smoking intensity and lipoprotein abnormalities in active smokers." Journal of Clinical Lipidology, 3 (6): 372378.

[35] Hunter K., Garlick P., Broom I.,. Anderson S. and Nurlan M.(2001) "Effects of smoking and abstention from smoking in fibrinogen synthesis in humans". Clinical Science, 100 (4): 459-65.

[36] Barua RS, Ambrose JA, Eales-Reynolds LJ, DeVoe MC, Zervas JG, Saha DC(2002) "Heavy and light cigarette smokers have similar dysfunction of endothelial vasoregulatory activity: an in vivo and in vitro correlation," Journal of the American College of Cardiology 39 (11): 1758-63.

[37] Hakovirta M. and Rantalaiho, M. (2012) "Economic inequality in children's everyday life, Kela." Helsinki: The Social Insurance Institution of Finland, Studies in social security and health $124 ; 143$.

[38] Layte R., McGee H., Quail A., Rundle K., Cousins G. and Donnelly C. (2006) "The Irish study of sexual health and relationships (ISSHR)." Dublin: Crisis Pregnancy Agency and Department of Health and Children.

[39] Arnold CL, Davis TC, Berkel HJ, Jackson RH, Nandy I, London S. (2001) Smoking status, reading level and knowledge of tobacco effects among low-income pregnant women. Preventive Medicine; 32: 313-320.
[40] Leigh J. (1998) "Parents' schooling and the correlation between education and frailty." Economics of Education Review, 17 (3), 349-358.

[41] Vereecken C., Keukelier E. and Maes L. (2004). "Influence of mother's educational level on food parenting practices and food habits of young children." Appetite, 43 (1): 93-103.

[42] Miech R. and Chilcoat H., (2005) "Maternal education and adolescent drug use: A longitudinal analysis of causation and selection over a generation." Social Science and Medicine, 60: 725-735.

[43] Zlot AI., Valdez R., Han Y., Silvey K. and Leman RF. (2010) "Influence of Family History of Cardiovascular Disease on Clinicians' Preventive Recommendations and subsequent adherence of patients without cardiovascular disease." Public Health Genomics, 13: 457-466.

[44] Rashed L., Abdel Hay R., Mahmoud R., Hasan N., Zahra A. and Fayez S. (2015) "Association of Angiotensin-Converting Enzyme (ACE) Gene Polymorphism with Inflammation and Cellular Cytotoxicity in Vitiligo Patients.” PLoS ONE 10 (7): $1-10$.

[45] Semmame O., Chellat D., Ziada H., Benchabi Y., Satta D. and Abadi N. (2015) "The Relationship Between the Insertion/Deletion Polymorphism of the AngiotensinConverting Enzyme Gene and Myocardial Infarction in Algerian Population.” International Journal of Pharmaceutical Sciences Review and Research, 35 (2): 156-161.

[46] Al-Serri A Ismael FG Al-Bustan S and Al-Rashdan I. (2015) "Association of the insertion allele of the common ACE gene polymorphism with type 2 diabetes mellitus among Kuwaiti cardiovascular disease patients." Journal of the ReninAngiotensin Aldosterone System, 16 (4): 910-916.

[47] AlBacha Jd., Khoury M., Mouawad C., Haddad K., Hamoui S., Azar A., Fajloun Z and Makdissy N. (2015) "High Incidence of ACE/PAI-1 in Association to a Spectrum of Other Polymorphic Cardiovascular Genes Involving PBMCs Proinflammatory Cytokines in Hypertensive Hypercholesterolemic Patients: Reversibility with a Combination of ACE Inhibitor and Statin.” PLoS ONE 10 (5): 1-24.

[48] Alharbi Kh., Kashour T., Al-Hussaini W., Al-Nbaheen M., Mohamed S., Hasanato R., Tamimi W., Al-Naami M. and Ali Khan I. (2013) "Association of angiotensin converting enzyme gene insertion/ deletion polymorphism and familial hypercholesterolemia in the Saudi population Lipids in Health and Disease." Lipids Health Disease 12 (177): 1-5.

[49] Inanir S., YIgIt S., CamCellke F., AteS O., ErdOgan taYcan S., NurSal Y. and Inanir A. (2016) "Relationship between major depressive disorder and $A C E$ gene $I / D$ polymorphism in a Turkish population.” Archives of Clinical Psychiatry, 43 (2): 27-30.

[50] Shanmuganathan R., Kumaresan R. Giri P. (2015) "Prevalence of angiotensin converting enzyme (ACE) gene insertion /deletion polymorphism in South Indian population with hypertension and chronic kidney disease." Journal of Postgraduate Medicine, 61 (4): 230-234.

[51] Carmen D., Claudia B., Zsuzsanna G., Alina G. and Horea G. (2011) "Association Between Angiotensin Converting Enzyme Gene Insertion (I) /Deletion (D) Polymorphism and Secondary Arterial Hypertension in a Romanian Children Population. Acta Medica Marisiensis, 4 (2247): 1-4. 
[52] Zhou L., Xi B., Wei Y., Shen W. and Yixiang Li. (2012) "Meta-analysis of the association between the insertion/deletion polymorphism in ACE gene and coronary heart disease among the Chinese population." Journal of the Renin-Angiotensin- Aldosterone System, 13 (2): 296- 304.

[53] Al-Jebouri M. and Al-Alwani H. (2015) “Angiotensin IConverting Enzyme Gene Polymorphism In Patients With Chronic Renal Failure". World Journal of Pharmaceutical Research, 4 (1): 1-11.

[54] Tseluyko VI., Litvinova IA. and Kravchenko NA. (2000) "Angiotensin-converting enzyme gene polymorphism in patients with hypertrophic cardiomyopathy." Ukrainian Journal of Cardiology, 3: 37-41.

[55] Bekmetova F., Ravshanbek D., Alexander B., Kurbanov D., Liliya E. and Shek K. (2012) "Association between $A C E$ Gene $I / D$ Polymorphism and Unstable Angina in Uzbek Patients with Family History of Coronary Heart Disease.” International Journal of Biomedicine 2 (4) 275-278.

[56] Malygina N., Kostomarova I., Krivodubskaya T. and Muromova SI. (2000) "Analysis of the angiotensin-converting enzyme gene polymorphism in patients with coronary heart disease and hypertension" Cardiology, 4: 2-19. 